\title{
Estimates of Krebs cycle activity and contributions of gluconeogenesis to hepatic glucose production in fasting healthy subjects and IDDM patients
}

\author{
B.R. Landau ${ }^{1}$, V. Chandramouli ${ }^{1}$, W. C. Schumann ${ }^{1}$, K. Ekberg ${ }^{2}$, K. Kumaran ${ }^{1}$, S. C. Kalhan ${ }^{3}$, J. Wahren ${ }^{2}$ \\ ${ }^{1}$ Department of Medicine, Case Western Reserve University, Cleveland, Ohio, USA \\ ${ }^{2}$ Department of Clinical Physiology, Karolinska Hospital, Stockholm, Sweden \\ ${ }^{3}$ Department of Pediatrics, Case Western Reserve University, Cleveland, Ohio, USA
}

Summary Normal subjects, fasted $60 \mathrm{~h}$, and patients with insulin-dependent diabetes mellitus (IDDM), withdrawn from insulin and fasted overnight, were given phenylacetate orally and intravenously infused with $\left[3-{ }^{14} \mathrm{C}\right]$ lactate and ${ }^{13} \mathrm{C}$-bicarbonate. Rates of hepatic gluconeogenesis relative to Krebs cycle rates were estimated from the ${ }^{14} \mathrm{C}$ distribution in glutamate from urinary phenylacetylglutamine. Assuming the ${ }^{13} \mathrm{C}$ enrichment of breath $\mathrm{CO}_{2}$ was that of the $\mathrm{CO}_{2}$ fixed by pyruvate, the enrichment to be expected in blood glucose, if all hepatic glucose production had been by gluconeogenesis, was then estimated. That estimate was compared with the actual enrichment in blood glucose, yielding the fraction of glucose production due to gluconeogenesis. Relative rates were similar in the 60 -h fasted healthy subjects and the diabetic patients. Conversion of oxaloacetate to phosphoenolpyruvate was two to eight times
Krebs cycle flux and decarboxylation of pyruvate to acetyl-CoA, oxidized in the cycle, was less than one30 th the fixation by pyruvate of $\mathrm{CO}_{2}$. Thus, in estimating the contribution of a gluconeogenic substrate to glucose production by measuring the incorporation of label from the labelled substrate into glucose, dilution of label at the level of oxaloacetate is relatively small. Pyruvate cycling was as much as onehalf the rate of conversion of pyruvate to oxaloacetate. Glucose and glutamate carbons were derived from oxaloacetate formed by similar pathways if not from a common pool. In the 60-h fasted subjects, over $80 \%$ of glucose production was via gluconeogenesis. In the diabetic subjects the percentages averaged about $45 \%$. [Diabetologia (1995) 38: 831-838]

Key words Gluconeogenesis, Krebs cycle, fasting, insulin-dependent diabetes mellitus, liver.
It is a continuing challenge to develop a method for reliably estimating the contribution of gluconeogenesis to glucose production in humans, so that it can be applied under both physiological and pathological conditions $[1,2]$. Measurements of incorporation of label into glucose on administration of a labelled gluconeogenic substrate are limited by the need to

Received: 12 October 1994 and in revised form: 13 January 1995

Corresponding author: Dr. B.R. Landau, Division of Molecular and Clinical Endocrinology, Case Western Reserve University School of Medicine, 10900 Euclid Avenue, Cleveland, Ohio 44106-4951, USA

Abbreviations: IDDM, Insulin-dependent diabetes mellitus; PEP, phosphoenolpyruvate. know the amount of label in the substrate entering the gluconeogenic process and the extent of dilution of label during that process, notably at the level of oxaloacetate, an intermediate common to the Krebs cycle and gluconeogenesis.

Phosphoenolpyruvate (PEP) is the necessary intermediate formed from oxaloacetate via pyruvate in the production of glucose (Fig. 1). We therefore gave ${ }^{14} \mathrm{C}$-labelled bicarbonate to fasted normal subjects, assuming the specific activity of expired ${ }^{14} \mathrm{CO}_{2}$ to be the specific activity of ${ }^{14} \mathrm{C}$ fixed in the conversion of oxaloacetate to pyruvate [3]. We did that because of evidence that expired ${ }^{14} \mathrm{CO}_{2}$ is a good measure of mitochondrial ${ }^{14} \mathrm{CO}_{2}$. We estimated the extent of dilution at the level of oxaloacetate from the distribution of ${ }^{14} \mathrm{C}$ from $\left[3-{ }^{14} \mathrm{C}\right]$ lactate in hepatic $\alpha-$ ketoglutarate, estimated from the distribution of ${ }^{14} \mathrm{C}$ 


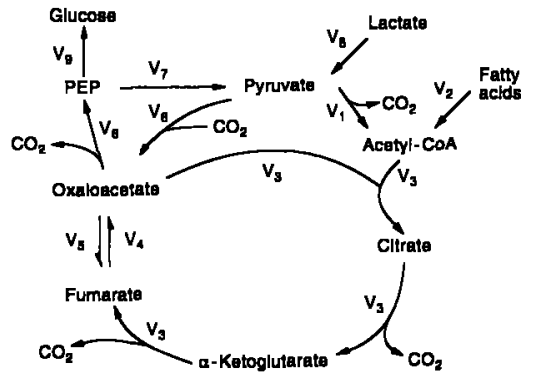

Fig.1 Scheme of pathways of gluconeogenesis and Krebs cycle metabolism in the liver. Rates are designated $V_{1}, V_{2}$, etc. in keeping with previous usage [4]

in glutamine conjugated to phenylacetate. Our method, while time consuming, provides details on the metabolic rates occurring in liver while offering a direct measure of the contribution of gluconeogenesis. We have now used that approach to examine the rate of gluconeogenesis relative to Krebs cycle flux and the contribution of gluconeogenesis to glucose production in insulin-dependent diabetic (IDDM) patients, withdrawn from insulin so as to develop mild ketosis. These findings have been compared with those observed in fasted normal subjects also in mild ketosis.

\section{Subjects, materials and methods}

Subjects. A healthy man and woman, ages 35 and 28 years, with body mass indices 26.0 and $22.0 \mathrm{~kg} / \mathrm{m}^{2}$, respectively, and fasted for $60 \mathrm{~h}$, were studied. Five males with IDDM, ages 19 to 23 years, with a mean body mass index of $22.9 \mathrm{~kg} / \mathrm{m}^{2}$ (range 18.0 to 26.8) were also studied. The haemoglobin $A_{1 c}$ concentration in four of the diabetic subjects ranged from 6.9 to $8.0 \%$ and in one subject, MP, it was $13.9 \%$. Insulin was withdrawn $24 \mathrm{~h}$ before the study and food was withheld for $12 \mathrm{~h}$. The diabetic subjects were encouraged to drink water throughout the period of insulin withdrawal. Approval for the study was obtained from the Human Investigation Committees at the Karolinska Hospital, Stockholm and University Hospitals of Cleveland. Informed consent was obtained from each subject.

Materials. $\left[3{ }^{14} \mathrm{C}\right]$ Lactate was prepared as previously described [4] from D-[6- $\left.{ }^{14} \mathrm{C}\right]$ glucose (purchased from Dupont-New England Nuclear, Boston, Mass., USA). ${ }^{13} \mathrm{C}$-labelled sodium bicarbonate, $99 \%$ enriched, was purchased from Merck Isotopes Inc., St. Louis, Mo., USA. The $\left[3-{ }^{14} \mathrm{C}\right]$ lactate infused was dissolved in 50 or $100 \mathrm{ml}$ of a sterile $0.154 \mathrm{~mol} / 1$ sodium chloride solution. The $5 \mathrm{~g}$ of bicarbonate infused was dissolved in $500 \mathrm{ml}$ of a sterile $0.077 \mathrm{~mol} / \mathrm{l}$ sodium chloride solution. The lactate and bicarbonate solutions were shown to be pyrogen-free.

Experimental protocol. The protocol was similar to that previously used $[3,4]$ except that the subjects were given ${ }^{13} \mathrm{C}$-labelled bicarbonate together with $\left[3-{ }^{14}\right]$ lactate. The two normal subjects and three of the diabetic subjects ingested $4.8 \mathrm{~g}$ of phenylacetate, divided into three $1.6-\mathrm{g}$ portions, at 30 -min intervals. At the time the second portion was ingested (designated zero time) an infusion was begun of the labelled lactate and bicarbonate. The $\left[3{ }^{14} \mathrm{C}\right]$ lactate $(40 \mu \mathrm{Ci})$ was infused in trace quantity, $8 \mu \mathrm{Ci}$ as a bolus and then the rest infused at a con- stant rate for the next $6 \mathrm{~h}$. Labelled bicarbonate $(5 \mathrm{~g})$ was infused at a constant rate over the 6-h period. In the other two diabetic subjects infusion was for $8 \mathrm{~h}$. Eighty $\mu \mathrm{Ci}$ of the [3$\left.{ }^{14} \mathrm{C}\right]$ lactate was given, $14 \mu \mathrm{Ci}$ as a bolus and the rest at a constant rate over the $8 \mathrm{~h}$. Phenylacetate $(4.8 \mathrm{~g})$, was ingested in divided portions between the second and third hour. Five grams of the labelled bicarbonate was infused, but the rate of infusion for the first hour was $55 \%$ and the second hour $90 \%$ of the rate over the next $6 \mathrm{~h}$.

Blood $(5$ to $10 \mathrm{ml})$ was drawn at hourly intervals for determinations of plasma glucose and $\mathrm{D}-\beta$-hydroxybutyrate concentrations. Blood for the isolation of glucose (70 to $110 \mathrm{ml}$ ), was drawn $90 \mathrm{~min}$ before and at the end of the infusion. Urine, for the isolation of urea and glutamate from excreted phenylacetyl-glutamine, was collected at 90 -min intervals over the last $3 \mathrm{~h}$ of infusion. Respiratory $\mathrm{CO}_{2}$ was collected at hourly intervals by having the subjects breathe into balloons. Subjects were encouraged to drink $180-240 \mathrm{ml}$ of water hourly during the infusion.

Measurements. Blood glucose, urinary urea, and glutamate from the excreted phenylacetylglutamine were isolated and degraded as previously described [4]. The urea carbon was collected as $\mathrm{BaCO}_{3}$ by using urease. Portions of the glucose and glutamate were diluted with known quantities of unlabelled glucose and glutamate. Portions of these were then combusted to $\mathrm{CO}_{2}$ and the remainder degraded to yield each of the carbons of the glucose and glutamate as $\mathrm{CO}_{2}$ that was also collected as $\mathrm{BaCO}_{3}$. Carbon 1 of the undiluted glutamate was isolated as $\mathrm{BaCO}_{3}$ by treatment of a portion of the glutamate with chloramine T. Carbons 3 and 4 of the undiluted glucose were isolated as $\mathrm{BaCO}_{3}$ by incubating the glucose with Lactobacillus delbrueckii to form lactate and decarboxylating the lactate. Respiratory $\mathrm{CO}_{2}$ was collected as barium carbonate by bubbling the expired breath through carbonate-free sodium hydroxide and then adding barium chloride.

${ }^{14} \mathrm{C}$-specific activities of the barium carbonates from urea, from the combustion of the diluted glucose and the diluted and undiluted glutamate, from the individual carbons of the diluted glucose and glutamate, and from breath $\mathrm{CO}_{2}$ were determined by liquid scintillation spectrometry. The excess enrichment of ${ }^{13} \mathrm{C}$ in the $\mathrm{BaCO}_{3}$ from urea, carbon 1 of the undiluted glutamate, the carboxyl group of lactate formed from the undiluted glucose and breath $\mathrm{CO}_{2}$ was determined by mass spectrometry [5]. Barium carbonates from glucose, urea glutamate and respiratory $\mathrm{CO}_{2}$ collected at zero time were assayed for the measure of ${ }^{13} \mathrm{C}$ natural abundance.

Calculations. Correction was made for the portion of the ${ }^{14} \mathrm{C}$ incorporated into glutamate that was due to the fixation of ${ }^{14} \mathrm{CO}_{2}$ formed from the $\left[3-{ }^{14} \mathrm{C}\right]$ lactate. The method for estimating the portion is based upon evidence that the bicarbonate utilized in urea formation and formation of oxaloacetate from pyruvate derive from the same pool of $\mathrm{CO}_{2}$ in hepatic mitochondria [3]. Carbon in $\mathrm{CO}_{2}$ fixed by pyruvate becomes carbon 1 of $\alpha$-ketoglutarate and hence carbon 1 of glutamate. ${ }^{14} \mathrm{CO}_{2}$ from $\left[3{ }^{14} \mathrm{C}\right]$ lactate should then be incorporated into carbon 1 of glutamate relative to its incorporation into urea in the same ratio as for ${ }^{13} \mathrm{C}$-bicarbonate. Therefore, for a given collection period: Specific Activity in Carbon 1 of Glutamate due to ${ }^{14} \mathrm{CO}_{2}$ Fixation/Specific Activity in Urea $={ }^{13} \mathrm{C}$ Excess in Glutamate $/{ }^{13} \mathrm{C}$ Excess in Urea. The enrichment in carbon 1 of glutamate and urea having been measured as well as the ${ }^{14} \mathrm{C}$ specific activity of urea, the specific activity in carbon 1 of glutamate due to ${ }^{14} \mathrm{CO}_{2}$ fixation was calculated. Because breath $\mathrm{CO}_{2}$ would be expected to reflect hepatic mitochondrial $\mathrm{CO}_{2}$, its specific activity and enrichment were also used 
Table 1. Specific activity and distribution of ${ }^{14} \mathrm{C}$ in glutamate corrected for ${ }^{14} \mathrm{C}$ incorporation from ${ }^{14} \mathrm{CO}_{2}$ into carbon 1

\begin{tabular}{|c|c|c|c|c|c|c|c|c|c|c|}
\hline \multirow[t]{2}{*}{ Subject } & \multirow{2}{*}{$\begin{array}{l}\text { Time } \\
\text { (h) }\end{array}$} & \multirow{2}{*}{$\begin{array}{l}\text { Specific activity } \\
(\mathrm{dpm} / \mu \mathrm{mol})\end{array}$} & \multirow{2}{*}{$\begin{array}{l}\text { Recovery } \\
(\%)\end{array}$} & \multirow{2}{*}{$\begin{array}{l}\text { Correction to } \\
\text { carbon } 1(\%)\end{array}$} & \multicolumn{5}{|c|}{$\%{ }^{14} \mathrm{C}$ in carbon } & \multirow{2}{*}{$\frac{\text { Carbon } 2}{\text { Carbon } 1}$} \\
\hline & & & & & 1 & 2 & 3 & 4 & 5 & \\
\hline \multicolumn{11}{|c|}{ Normal subjects } \\
\hline $\mathrm{HJ}$ & $\begin{array}{l}3-4^{1 / 2} \\
41 / 2-6\end{array}$ & $\begin{array}{l}17.3 \\
12.9\end{array}$ & $\begin{array}{l}103.1 \\
108.1\end{array}$ & $\begin{array}{l}30.5(24.3) \\
32.6(32.1)\end{array}$ & $\begin{array}{l}5.5 \\
6.3\end{array}$ & $\begin{array}{l}45.2 \\
43.7\end{array}$ & $\begin{array}{l}41.9 \\
40.9\end{array}$ & $\begin{array}{l}5.9 \\
7.8\end{array}$ & $\begin{array}{l}1.5 \\
1.5\end{array}$ & $\begin{array}{l}8.2 \\
6.9\end{array}$ \\
\hline JE & $\begin{array}{l}3-4^{1 / 2} \\
4^{1 /} / 2-6\end{array}$ & $\begin{array}{l}21.7 \\
24.1\end{array}$ & $\begin{array}{l}92.7 \\
97.1\end{array}$ & $\begin{array}{l}26.8(23.1) \\
28.6(30.5)\end{array}$ & $\begin{array}{l}8.8 \\
7.0\end{array}$ & $\begin{array}{l}44.2 \\
44.8\end{array}$ & $\begin{array}{l}42.1 \\
41.7\end{array}$ & $\begin{array}{l}3.9 \\
5.2\end{array}$ & $\begin{array}{l}1.1 \\
1.3\end{array}$ & $\begin{array}{l}5.0 \\
6.4\end{array}$ \\
\hline \multicolumn{11}{|c|}{ IDDM subjects } \\
\hline $\mathrm{KR}$ & $4^{1} / 2-6$ & 15.1 & 91.6 & $33.7(26.8)$ & 6.6 & 49.7 & 36.1 & 6.4 & 1.2 & 7.5 \\
\hline MP & $\begin{array}{l}3-4^{1 / 2} \\
4^{1 / 1} 2^{-6}\end{array}$ & $\begin{array}{l}8.6 \\
9.0\end{array}$ & $\begin{array}{l}80.4 \\
90.1\end{array}$ & $\begin{array}{l}40.0(27.2) \\
37.5(30.1)\end{array}$ & $\begin{array}{l}6.2 \\
5.8\end{array}$ & $\begin{array}{l}49.7 \\
53.8\end{array}$ & $\begin{array}{l}37.8 \\
34.0\end{array}$ & $\begin{array}{l}4.9 \\
4.9\end{array}$ & $\begin{array}{l}1.4 \\
1.7\end{array}$ & $\begin{array}{l}8.0 \\
9.3\end{array}$ \\
\hline RL & $\begin{array}{l}3-4^{1 /} / 2 \\
4 \frac{1}{2}-6\end{array}$ & $\begin{array}{l}16.3 \\
22.5\end{array}$ & $\begin{array}{l}95.0 \\
96.5\end{array}$ & $\begin{array}{l}15.7(9.1) \\
20.3(16.7)\end{array}$ & $\begin{array}{l}7.3 \\
7.2\end{array}$ & $\begin{array}{l}50.5 \\
49.7\end{array}$ & $\begin{array}{l}34.9 \\
35.6\end{array}$ & $\begin{array}{l}7.0 \\
6.8\end{array}$ & $\begin{array}{l}0.4 \\
0.6\end{array}$ & $\begin{array}{l}8.2 \\
6.9\end{array}$ \\
\hline $\mathrm{JG}^{\mathrm{a}}$ & $61 / 2-8$ & 22.6 & 96.4 & $57.5(53.2)$ & 3.7 & 48.0 & 41.6 & 4.9 & 1.8 & 13.0 \\
\hline TS & $\begin{array}{l}5-6^{1 / 2} \\
61 / 2-8\end{array}$ & $\begin{array}{l}21.8 \\
11.4\end{array}$ & $\begin{array}{r}101.4 \\
90.0\end{array}$ & $\begin{array}{l}33.8(29.3) \\
31.8(27.9)\end{array}$ & $\begin{array}{l}9.5 \\
8.6\end{array}$ & $\begin{array}{l}51.2 \\
52.6\end{array}$ & $\begin{array}{l}32.5 \\
32.8\end{array}$ & $\begin{array}{l}5.9 \\
4.9\end{array}$ & $\begin{array}{l}0.9 \\
1.1\end{array}$ & $\begin{array}{l}5.4 \\
6.1\end{array}$ \\
\hline
\end{tabular}

a JG was unable to provide a urine for collection from $5-6 \frac{1}{2}$ h. The specific activity of glutamate from phenylacetylglutamine excreted from $6-6 \frac{1}{2} \mathrm{~h}$ was $25.1 \mathrm{dpm} / \mu \mathrm{mol}$

to calculate the correction due to ${ }^{14} \mathrm{CO}_{2}$ fixation. Thus, Specific Activity in Carbon 1 of Glutamate due to ${ }^{14} \mathrm{CO}_{2}$ Fixation/Specific Activity in Breath $\mathrm{CO}_{2}={ }^{13} \mathrm{C}$ Excess in Glutamate $/{ }^{13} \mathrm{C} \mathrm{Ex}$ cess in Breath $\mathrm{CO}_{2}$.

For the estimation of the incorporation of ${ }^{14} \mathrm{C}$ from ${ }^{14} \mathrm{CO}_{2}$ into carbon 3 and 4 of glucose, the measurements of the specific activity and excess enrichment of urea were again employed along with the measurement of the excess enrichment of ${ }^{13} \mathrm{C}$ in glucose. Since carbon from $\mathrm{CO}_{2}$ that is fixed is only incorporated into carbons 3 and 4 of glucose [4]: Specific Activity of Carbons 3 and 4 of Glucose due to ${ }^{14} \mathrm{CO}_{2}$ fixation/Specific Activity of Urea $={ }^{13} \mathrm{C}$ Excess in Glucose $/{ }^{13} \mathrm{C}$ Excess in Urea. Corrections were similarly made using the specific activities and enrichments in breath $\mathrm{CO}_{2}$ rather than those for urea.

From the distribution of ${ }^{14} \mathrm{C}$ from $\left[3-{ }^{14} \mathrm{C}\right]$ lactate in the carbons of glutamate from urinary phenylacetylglutamine, assumed to be an adequate reflection of the distribution in hepatic $\alpha$-ketoglutarate, relative rates were estimated for the reactions in gluconeogenesis and the Krebs cycle (Fig.1), i.e. pyruvate to acetyl-CoA, fatty acids to acetyl-CoA, fumarate to oxaloacetate, oxaloacetate to fumarate, oxaloacetate to PEP, PEP to pyruvate, lactate to pyruvate and PEP to glucose. The equations expressing those relationships, as well as an examination of the assumptions made in their derivation, have been presented [4].

The ${ }^{13} \mathrm{C}$ enrichment of carbon 1 of PEP, designated $\mathrm{E}_{1}$, relative to that of the $\mathrm{CO}_{2}$ fixed by pyruvate, depends upon the equilibration of oxaloacetate with fumarate, the rate of gluconeogenesis relative to Krebs cycle flux and the extent of pyruvate cycling, i.e. pyruvate $\rightarrow$ oxaloacetate $\rightarrow \mathrm{PEP} \rightarrow$ pyruvate, and/or Cori cycling, i.e. pyruvate $\rightarrow$ glucose $\rightarrow$ pyruvate [3]. The equation, previously derived [3], used to estimate $E_{1}$, assuming no pyruvate or Cori cycling, is

$\mathrm{E}_{1}=\frac{0.5 \mathrm{~V}_{5} \mathrm{~V}_{6} \mathrm{D}}{\left(\mathrm{V}_{4}+\mathrm{V}_{6}\right)^{2}-\left(\mathrm{V}_{4} \mathrm{~V}_{5}+\mathrm{V}_{5} \mathrm{~V}_{6}\right)}$

and in the presence of significant pyruvate and/or Cori cycling

$E_{1}=\frac{V_{6}\left[0.5 D V_{5}+P_{1}\left(V_{4}+V_{6}-0.5 V_{5}\right)\right]}{\left(V_{4}+V_{6}\right)^{2}-\left(V_{4} V_{5}+V_{5} V_{6}\right)}$ where $\mathrm{V}_{4}$ is the rate of conversion of fumarate to oxaloacetate, $V_{5}$ that of the conversion of oxaloacetate to fumarate and $V_{6}$ that of the conversion of oxaloacetate to PEP (Fig.1), all relative to the rate of Krebs cycle flux. $P_{1}$ is the enrichment of carbon 1 of pyruvate, equal to $V_{7} E_{1} /\left(V_{7}+V_{8}\right)$ where $V_{7}$ is the relative rate of the conversion of PEP to pyruvate and $V_{8}$ that of the conversion of lactate to pyruvate. $\mathrm{D}$ is the enrichment of the $\mathrm{CO}_{2}$ fixed by the pyruvate, assumed to be that in breath $\mathrm{CO}_{2}$. The enrichment in carbon 1 of PEP is then half the enrichment to be expected in glucose, i. e. in its carbons 3 and 4 , if all glucose production were from gluconeogenesis via PEP. Then $100\left({ }^{13} \mathrm{C}\right.$ Excess Enrichment in Glucose $) / 2 \mathrm{E}_{1}$ equals the $\%$ of glucose production by gluconeogenesis [3]. That equals 100(Enrichment in Carbon 1 of Lactate obtained by incubating the glucose with Lactobacillus delbrueckii)/ $\mathrm{E}_{1}$.

\section{Results}

Distribution of ${ }^{14} \mathrm{C}$ in glutamate. Carbon 1 of the glutamate from the $61 / 2-8 \mathrm{~h}$ collection of subject had a ${ }^{13} \mathrm{C}$ excess enrichment about one-half that from the $5-6 \frac{1}{2} \mathrm{~h}$ collection (Table 1 ). However, the specific activities and enrichments of his breath $\mathrm{CO}_{2}$, reflecting the enrichments in the $\mathrm{CO}_{2}$ fixed in the incorporation of ${ }^{13} \mathrm{C}$ into carbon 1 of the glutamate were almost the same in the two periods. Therefore, there was dilution of phenylacetylglutamine or glutamate between the time of the $6 \frac{1}{2}-8 \mathrm{~h}$ urine was collected and the total combustion, but we have been unable to determine how that occurred.

The distributions of ${ }^{14} \mathrm{C}$ in the glutamate carbons have been corrected for the incorporation of ${ }^{14} \mathrm{C}$ into carbon 1 of glutamate due to fixation of ${ }^{14} \mathrm{C}$ from ${ }^{14} \mathrm{CO}_{2}$ formed from the $\left[3-{ }^{14} \mathrm{C}\right]$ lactate. The percentage corrections not in parentheses are those estimated using the specific activity of urea. It was those percentages that were used in calculating the distribu- 
Table 2. Glucose and hydroxybutyrate concentrations, glucose specific activity, and distribution of ${ }^{14} \mathrm{C}$ in glucose corrected for ${ }^{14} \mathrm{C}$ incorporation from ${ }^{14} \mathrm{CO}_{2}$ into carbons 3 and 4

\begin{tabular}{|c|c|c|c|c|c|c|c|c|c|c|c|c|c|}
\hline \multirow{2}{*}{$\begin{array}{l}\text { Sub- } \\
\text { ject }\end{array}$} & \multirow{2}{*}{$\begin{array}{l}\text { Time } \\
\text { (b) }\end{array}$} & \multirow{2}{*}{$\begin{array}{l}\text { Glucose } \\
\text { concen- } \\
\text { tration } \\
(\mathrm{mmol} / \mathrm{l})\end{array}$} & \multirow{2}{*}{$\begin{array}{l}\text { Hydroxybu- } \\
\text { tyrate con- } \\
\text { centration } \\
\text { (mmol/l) }\end{array}$} & \multirow{2}{*}{$\begin{array}{l}\text { Specific } \\
\text { activity } \\
(\mathrm{dpm} / \mu \mathrm{mol})\end{array}$} & \multirow{2}{*}{$\begin{array}{l}\text { Reco- } \\
\text { very } \\
(\%)\end{array}$} & \multirow{2}{*}{$\begin{array}{l}\text { Correction } \\
\text { to carbons } \\
3 \text { and } 4(\%)\end{array}$} & \multicolumn{6}{|c|}{$\%{ }^{14} \mathrm{C}$ in carbons } & \multirow{2}{*}{$\begin{array}{l}\text { Carbons } \\
1+6 \\
\text { Carbons } \\
3+4\end{array}$} \\
\hline & & & & & & & 1 & 2 & 3 & 4 & 5 & 6 & \\
\hline \multicolumn{14}{|c|}{ Normal subjects } \\
\hline $\mathrm{HJ}$ & 6 & $4.0(3.3)$ & 2.8 & 152.3 & 96.0 & $29.0(27.6)$ & 25.6 & 21.3 & 2.6 & 2.6 & 21.7 & 26.1 & 9.9 \\
\hline $\mathrm{JE}$ & 6 & $3.8(3.3)$ & 3.1 & $155.9^{\mathrm{a}}$ & 93.8 & $33.3(34.8)$ & 24.8 & 22.7 & 2.5 & 2.4 & 21.0 & 26.4 & 10.4 \\
\hline \multicolumn{14}{|c|}{ IDDM subjects } \\
\hline $\mathrm{KR}$ & $\begin{array}{l}4^{1 / 2} \\
6\end{array}$ & $13.1(13.9)$ & & $\begin{array}{l}45.5 \\
63.6\end{array}$ & $\begin{array}{r}100.3 \\
99.2\end{array}$ & $\begin{array}{l}12.7(19.1) \\
12.1(19.1)\end{array}$ & $\begin{array}{l}22.2 \\
22.8\end{array}$ & $\begin{array}{l}18.3 \\
18.9\end{array}$ & $\begin{array}{l}2.8 \\
2.8\end{array}$ & $\begin{array}{l}3.1 \\
2.1\end{array}$ & $\begin{array}{l}23.1 \\
23.9\end{array}$ & $\begin{array}{l}30.6 \\
28.5\end{array}$ & $\begin{array}{l}8.9 \\
8.7\end{array}$ \\
\hline MP & $\begin{array}{l}4^{1 / 2} 2 \\
6\end{array}$ & $18.4(20.1)$ & 1.1 & $\begin{array}{l}27.3 \\
32.4\end{array}$ & $\begin{array}{r}100.2 \\
98.3\end{array}$ & $\begin{array}{l}11.9(16.6) \\
12.4(20.4)\end{array}$ & $\begin{array}{l}19.4 \\
20.3\end{array}$ & $\begin{array}{l}17.4 \\
16.6\end{array}$ & $\begin{array}{l}3.7 \\
3.2\end{array}$ & $\begin{array}{l}4.4 \\
4.3\end{array}$ & $\begin{array}{l}25.2 \\
25.1\end{array}$ & $\begin{array}{l}30.0 \\
30.5\end{array}$ & $\begin{array}{l}6.1 \\
6.8\end{array}$ \\
\hline RL & $\begin{array}{l}4 \frac{1}{1} / 2 \\
6\end{array}$ & $14.8(20.4)$ & 3.1 & $\begin{array}{l}69.5 \\
93.4\end{array}$ & $\begin{array}{l}98.6 \\
99.4\end{array}$ & $\begin{array}{l}31.4(18.2) \\
21.2(17.5)\end{array}$ & $\begin{array}{l}22.7 \\
23.6\end{array}$ & $\begin{array}{l}18.6 \\
18.4\end{array}$ & $\begin{array}{l}2.1 \\
2.8\end{array}$ & $\begin{array}{l}2.5 \\
3.0\end{array}$ & $\begin{array}{l}23.6 \\
23.3\end{array}$ & $\begin{array}{l}30.6 \\
29.0\end{array}$ & $\begin{array}{r}11.6 \\
9.1\end{array}$ \\
\hline JG & $\begin{array}{l}6^{1 / 1} \\
8\end{array}$ & $19.6(15.7)$ & 2.3 & $\begin{array}{l}107.9 \\
123.5\end{array}$ & $\begin{array}{l}94.6 \\
98.0\end{array}$ & $\begin{array}{l}31.4(26.6) \\
33.2(29.6)\end{array}$ & $\begin{array}{l}24.0 \\
24.0\end{array}$ & $\begin{array}{l}20.5 \\
20.4\end{array}$ & $\begin{array}{l}2.8 \\
2.7\end{array}$ & $\begin{array}{l}3.1 \\
3.0\end{array}$ & $\begin{array}{l}23.4 \\
22.1\end{array}$ & $\begin{array}{l}26.0 \\
27.8\end{array}$ & $\begin{array}{l}8.5 \\
9.1\end{array}$ \\
\hline TS & $\begin{array}{l}6^{1 / 2} \\
8\end{array}$ & $17.7(20.2)$ & 1.5 & $\begin{array}{l}64.8 \\
85.5\end{array}$ & $\begin{array}{l}97.2 \\
97.7\end{array}$ & $\begin{array}{l}35.3(30.6) \\
34.0(29.8)\end{array}$ & $\begin{array}{l}22.2 \\
23.3\end{array}$ & $\begin{array}{l}17.9 \\
18.8\end{array}$ & $\begin{array}{l}2.1 \\
2.4\end{array}$ & $\begin{array}{l}2.7 \\
2.7\end{array}$ & $\begin{array}{l}24.7 \\
23.5\end{array}$ & $\begin{array}{l}30.3 \\
29.1\end{array}$ & $\begin{array}{r}10.9 \\
9.9\end{array}$ \\
\hline
\end{tabular}

a $144.3 \mathrm{dpm} / \mu \mathrm{mol}$ at $4 \frac{1}{2} \mathrm{~h}$

tions. Thus, for the glutamate from subject $\mathrm{HJ}$ collected at $3-4 \frac{1}{2} \mathrm{~h}, 30.5 \%$ of the ${ }^{14} \mathrm{C}$ formed in its carbon 1 was due to ${ }^{14} \mathrm{CO}_{2}$ fixation. Therefore, the $\%$ of ${ }^{14} \mathrm{C}$ in carbon 1 before correction was $7.9 \%$ and after correction the $5.5 \%$ recorded. The $\%$ corrections in parentheses are those calculated using the specific activities and enrichments in breath $\mathrm{CO}_{2}$ rather than urea. The corrections calculated using the average specific activities and enrichments in breath $\mathrm{CO}_{2}$ during the period of the collection are about $15 \%$ lower on average than those using urea.

The ${ }^{14} \mathrm{C}$ in each of the five carbons of glutamate are recorded as a\% of the sum of the ${ }^{14} \mathrm{C}$ in the five carbons. The distributions in different collection periods for a given subject are similar. Over $80 \%$ of the ${ }^{14} \mathrm{C}$ in glutamate was in carbons 2 and 3 . The ratios of ${ }^{14} \mathrm{C}$ in carbon 3 to carbon 2 of glutamate from the diabetic patients, except JG, range from 0.63 to 0.76 . The ratios for JG and the subjects fasted for $60 \mathrm{~h}$ range from 0.86 to 0.95 .

Distribution of ${ }^{14} \mathrm{C}$ in glucose. After $60 \mathrm{~h}$ of fasting, normal subjects, as in our previous experience $[3,4]$, had plasma glucose concentrations of about $4.0 \mathrm{mmol} / \mathrm{l}$ and $6 \mathrm{~h}$ later about $3.3 \mathrm{mmol} / \mathrm{l}$ (Table 2). The plasma concentration of $\beta$-hydroxybutyrate at the completion of infusion provides evidence for mild ketosis in all the subjects, except in subject KR for whom the concentration was not determined.

Specific activities of glucose were highest in the normal subjects fasted for $60 \mathrm{~h}$ and next in subject JG. The specific activity of glucose $1 \frac{1}{2} \mathrm{~h}$ before completing the infusion was 72 to $84 \%$ of that at its completion. For the correction for the incorporation of ${ }^{14} \mathrm{C}$ into carbon 3 and 4 of glucose, the measurements of the specific activity and excess enrichment of urea were again employed along with the measurement of the excess enrichment of ${ }^{13} \mathrm{C}$ in glucose. The values in parentheses are the corresponding\% corrections using the specific activities and enrichments in breath $\mathrm{CO}_{2}$. Percent corrections estimated using breath $\mathrm{CO}_{2}$ are generally somewhat lower than those using urea except for subjects $\mathrm{KR}$ and MP where the corrections using urea are about one-third less than those using breath $\mathrm{CO}_{2}$.

Over $90 \%$ of the ${ }^{14} \mathrm{C}$ in glucose was in its carbons $1,2,5$ and 6 , with about $80 \%$ as much ${ }^{14} \mathrm{C}$ in carbon 2 as 1 and in carbon 5 as 6 . The difference in the \% of ${ }^{14} \mathrm{C}$ in carbon 6 to carbon 1 among the subjects is lowest for the two normal fasted subjects and next lowest for subject JG. Similarly, the differences are smallest between carbons 5 and 2 for the normal subjects and then subject JG. While the percentages of ${ }^{14} \mathrm{C}$ in carbons 3 and 4 are small, only in the normal subjects is the activity in carbon 3 equal to that in carbon 4 . Thus, in the diabetic subjects, ${ }^{14} \mathrm{C}$ in carbon 4 exceeds that in carbon 3, except for subject KR at $6 \mathrm{~h}$ and that is undoubtedly in error, since ${ }^{14} \mathrm{C}$ in carbon 6 exceeds that in carbon 1 and in carbon 5 that in carbon 2 .

Relative rates and gluconeogenesis. Rates estimated from the distributions in Table 1 are presented in Table 3. These rates are relative to the rate of Krebs cycle flux set to 1.0 , i.e. the rate acetyl-CoA condensed with oxaloacetate to form citrate. More than nine times as much of the acetyl-CoA condensing with oxaloacetate was from fatty acids as from pyruvate in both the fasted normal and the diabetic subjects. The rate of the conversion of oxaloacetate to fumarate in the $60-\mathrm{h}$ fasted subjects was more than 50 times the 
Table 3. Rates of reactions in gluconeogenesis and the Krebs cycle relative to Krebs cycle flux

\begin{tabular}{|c|c|c|c|c|c|c|c|c|c|}
\hline Subject & $\begin{array}{l}\text { Time } \\
\text { (h) }\end{array}$ & $\begin{array}{l}\text { Pyruvate } \rightarrow \\
\text { acetyl-CoA }\end{array}$ & $\begin{array}{l}\text { Fatty acids } \rightarrow \\
\text { acetyl-CoA }\end{array}$ & $\begin{array}{l}\text { Fumarate } \\
\rightarrow \text { oxaloacetate }\end{array}$ & $\begin{array}{l}\text { Oxaloacetate } \\
\rightarrow \text { fumarate }\end{array}$ & $\begin{array}{l}\text { Oxaloacetate } \\
\rightarrow \text { PEP }\end{array}$ & $\begin{array}{l}\mathrm{PEP} \rightarrow \\
\text { pyruvate }\end{array}$ & $\begin{array}{l}\text { Lactate } \rightarrow \\
\text { pyruvate }\end{array}$ & $\begin{array}{l}\text { PEP } \rightarrow \\
\text { glucose }\end{array}$ \\
\hline \multicolumn{10}{|c|}{ Normal subjects } \\
\hline $\mathrm{HJ}$ & $\begin{array}{l}3-41 / 2 \\
41 / 2-6\end{array}$ & $\begin{array}{l}0.08 \\
0.10\end{array}$ & $\begin{array}{l}0.92 \\
0.90\end{array}$ & $\begin{array}{l}68.4 \\
70.2\end{array}$ & $\begin{array}{l}67.4 \\
69.2\end{array}$ & $\begin{array}{l}4.18 \\
3.16\end{array}$ & $\begin{array}{l}1.99 \\
1.23\end{array}$ & $\begin{array}{l}2.37 \\
2.20\end{array}$ & $\begin{array}{l}2.19 \\
1.93\end{array}$ \\
\hline $\mathrm{JE}$ & $\begin{array}{l}3-4^{1 / 2} \\
41 / 2-6\end{array}$ & $\begin{array}{l}0.05 \\
0.07\end{array}$ & $\begin{array}{l}0.95 \\
0.93\end{array}$ & $\begin{array}{l}57.9 \\
54.4\end{array}$ & $\begin{array}{l}56.9 \\
53.4\end{array}$ & $\begin{array}{l}2.14 \\
2.97\end{array}$ & $\begin{array}{l}1.20 \\
1.45\end{array}$ & $\begin{array}{l}0.99 \\
1.58\end{array}$ & $\begin{array}{l}0.94 \\
1.52\end{array}$ \\
\hline \multicolumn{10}{|c|}{ IDDM subjects } \\
\hline MP & $\begin{array}{l}4-2^{-6} \\
3-4^{1} / 2 \\
41 / 2-6\end{array}$ & $\begin{array}{l}0.08 \\
0.06 \\
0.07\end{array}$ & $\begin{array}{l}0.92 \\
0.94 \\
0.93\end{array}$ & $\begin{array}{r}15.0 \\
14.8 \\
7.1\end{array}$ & $\begin{array}{r}12.0 \\
13.8 \\
6.1\end{array}$ & $\begin{array}{l}3.40 \\
4.11 \\
5.16\end{array}$ & $\begin{array}{l}1.52 \\
2.42 \\
3.85\end{array}$ & $\begin{array}{l}2.02 \\
1.76 \\
1.37\end{array}$ & $\begin{array}{l}1.94 \\
1.70 \\
1.31\end{array}$ \\
\hline RL & $\begin{array}{l}3-4^{1 / 2} \\
4^{1 / 2}-6\end{array}$ & $\begin{array}{l}0.07 \\
0.07\end{array}$ & $\begin{array}{l}0.93 \\
0.93\end{array}$ & $\begin{array}{l}12.8 \\
13.7\end{array}$ & $\begin{array}{l}11.8 \\
12.7\end{array}$ & $\begin{array}{l}2.65 \\
2.75\end{array}$ & $\begin{array}{l}0.43 \\
0.65\end{array}$ & $\begin{array}{l}2.29 \\
2.17\end{array}$ & $\begin{array}{l}2.22 \\
2.10\end{array}$ \\
\hline$J G$ & $61 / 2-8$ & 0.07 & 0.93 & 46.8 & 45.8 & 7.98 & 4.94 & 3.11 & 3.04 \\
\hline TS & $\begin{array}{l}5-6^{1 / 2} \\
6^{1 / 2}-8\end{array}$ & $\begin{array}{l}0.06 \\
0.06\end{array}$ & $\begin{array}{l}0.94 \\
0.94\end{array}$ & $\begin{array}{l}6.5 \\
6.1\end{array}$ & $\begin{array}{l}5.5 \\
5.1\end{array}$ & $\begin{array}{l}2.06 \\
2.67\end{array}$ & $\begin{array}{l}0.91 \\
1.57\end{array}$ & $\begin{array}{l}1.21 \\
1.15\end{array}$ & $\begin{array}{l}1.15 \\
1.09\end{array}$ \\
\hline
\end{tabular}

Table 4. Comparison of breath $\mathrm{CO}_{2}{ }^{14} \mathrm{C}$ specific activities and ${ }^{13} \mathrm{C}$ enrichments at $3 \mathrm{~h}$ relative to $6 \mathrm{~h}$ into the infusions of [3$\left.{ }^{14} \mathrm{C}\right]$ lactate and ${ }^{13} \mathrm{C}$-labelled bicarbonate

\begin{tabular}{lll}
\hline Subject & \multicolumn{2}{l}{ Ratio at $3 \mathrm{~h}$ to $6 \mathrm{~h}$} \\
\cline { 2 - 3 } & ${ }^{14} \mathrm{C}$ Specific activity & ${ }^{13} \mathrm{C}$ Excess enrichment \\
\hline HJ & 0.81 & 0.88 \\
JE & 0.71 & 0.91 \\
KR & 0.75 & 0.80 \\
MP & 0.78 & 0.83 \\
RL & 0.79 & 0.85 \\
JG & 0.84 & 0.92 \\
TS & 0.81 & 0.85 \\
\hline
\end{tabular}

Table 5. Ratio of the incorporation of ${ }^{14} \mathrm{C}$ into carbons 2 and 5 to carbons 1 and 6 of glucose divided by the ratio of the incorporation into carbons 3 to 2 of glutamate

\begin{tabular}{|c|c|c|}
\hline \multirow[t]{2}{*}{ Subject } & \multirow{2}{*}{$\begin{array}{l}\text { Time (h) } \\
\text { Glucose/Glutamate }\end{array}$} & \multirow{2}{*}{$\begin{array}{l}\text { Glucose ratio } \\
\text { Glutamate ratio }\end{array}$} \\
\hline & & \\
\hline \multicolumn{3}{|c|}{ Normal subjects } \\
\hline HG & $6 / 41 / 2-6$ & $0.83 / 0.94=0.88$ \\
\hline $\mathrm{JE}$ & $6 / 4^{1} / 2-6$ & $0.85 / 0.93=0.91$ \\
\hline $\mathrm{MH}^{\mathrm{a}}$ & $\begin{array}{l}41 / 2 / 3-41 / 2 \\
6 / 4^{1} / 2-6\end{array}$ & $\begin{array}{l}0.82 / 0.71=1.15 \\
0.83 / 0.81=1.02\end{array}$ \\
\hline $\mathbf{A K}^{\mathrm{a}}$ & $\begin{array}{l}41 / 2 / 3-41 / 2 \\
6 / 41 / 2-6\end{array}$ & $\begin{array}{l}0.83 / 0.81=1.02 \\
0.84 / 0.70=1.20\end{array}$ \\
\hline \multicolumn{3}{|c|}{ IDDM subjects } \\
\hline KR & $6 / 4^{1} / 2-6$ & $0.83 / 0.73=1.14$ \\
\hline MP & $\begin{array}{l}41 / 2 / 3-41 / 2 \\
6 / 4^{1} / 2-6\end{array}$ & $\begin{array}{l}0.86 / 0.76=1.13 \\
0.82 / 0.63=1.30\end{array}$ \\
\hline RL & $\begin{array}{l}41 / 2 / 3-4^{1} / 2 \\
6 / 4^{1} / 2-6\end{array}$ & $\begin{array}{l}0.79 / 0.69=1.14 \\
0.79 / 0.72=1.10\end{array}$ \\
\hline JG & $8 / 6^{1} / 2^{-8}$ & $0.81 / 0.90=0.90$ \\
\hline TS & $\begin{array}{l}6^{1} / 2 / 5-6^{1} / 2 \\
8 / 6^{1} / 2-8\end{array}$ & $\begin{array}{l}0.81 / 0.63=1.29 \\
0.81 / 0.63=1.31\end{array}$ \\
\hline
\end{tabular}

From reference 4 rate of Krebs cycle flux. In the diabetic subjects, again with the exception of JG, it was 5 to 14 times more. The rate of conversion of oxaloacetate to PEP was two to five times more, except for JG where it was eight times more, and with no discernible difference between the groups. About half of the PEP was converted to glucose and the remainder to pyruvate and again with no discernible difference between the groups. Thus, the rate of carboxylation of pyruvate to oxaloacetate, equal to the rate of conversion of oxaloacetate to PEP, was 30 times or more than the rate of its decarboxylation to acetyl-CoA. About $50 \%$ of the PEP formed was cycled.

The specific activity and enrichment in breath $\mathrm{CO}_{2}$ approached a plateau by the third hour (Table 4). At $5 \mathrm{~h}$, the specific activity of the breath $\mathrm{CO}_{2}$ was $88 \%$ or more and of ${ }^{13} \mathrm{C} 93 \%$ or more of that at $6 \mathrm{~h}$. Thus, while it was only a small difference, the specific activity of breath $\mathrm{CO}_{2}$ approached a plateau more slowly than its enrichment.

The ratio of incorporation of ${ }^{14} \mathrm{C}$ into carbons 2 and 5 to carbons 1 and 6 of glucose (Table 2) divided by the ratios of the incorporations of ${ }^{14} \mathrm{C}$ into carbons 3 to 2 of glutamate (Table 1) are about 1.0 (Table 5). The ratios for the diabetic subjects average 1.16 .

Estimates of $E_{1}$ during the last $1 \frac{1}{2} h$ of infusion, using for $\mathrm{D}$ the average ${ }^{13} \mathrm{C}$ enrichment in breath $\mathrm{CO}_{2}$ for that period, are recorded in columns 3 and 4 of Table 6. The mean of the enrichments in carbon 3 and 4 of circulating glucose, determined by conversion of the glucose to lactate and decarboxylation of the lactate, is recorded in the fifth column. The estimated percentage of glucose production due to gluconeogenesis is then 100 times $E_{1}$ divided by the mean of the enrichments in carbons 3 and 4 of the glucose. Those estimates are recorded in the last two columns of Table 6. 
Table 6. ${ }^{13} \mathrm{C}$ Excess estimated in carbon 1 of PEP $\left(E_{1}\right)$ and half that observed in carbons 3 and 4 of glucose; estimated \% glucose formation via gluconeogenesis

\begin{tabular}{|c|c|c|c|c|c|c|}
\hline \multirow[t]{2}{*}{ Subject } & \multirow[t]{2}{*}{$\begin{array}{l}\text { Time } \\
\text { (h) }\end{array}$} & \multicolumn{2}{|c|}{$\begin{array}{l}\text { Estimated excess }{ }^{13} \mathrm{C} \text { in } \mathrm{E}_{1} \\
\text { Pyruvate cycling }\end{array}$} & \multirow[t]{2}{*}{$\begin{array}{l}\text { Observed Excess }{ }^{13} \mathrm{C} \text { in } \\
\text { carbons } 3 \text { and } 4 \text { of glucose } / 2\end{array}$} & \multicolumn{2}{|c|}{$\begin{array}{l}\% \text { Gluconeogenesis } \\
\text { Pyruvate cycling }\end{array}$} \\
\hline & & Absent & Present & & Absent & Present \\
\hline \multicolumn{7}{|c|}{ Normal subjects } \\
\hline $\mathrm{HJ}$ & $4 \frac{1}{2}-6$ & 0.316 & 0.370 & 0.268 & 84.8 & 72.4 \\
\hline $\mathrm{JE}$ & $4 \frac{1}{2}-6$ & 0.396 & 0.489 & 0.346 & 87.4 & 70.8 \\
\hline \multicolumn{7}{|c|}{ IDDM subjects } \\
\hline $\mathrm{KR}$ & $41 / 2-6$ & 0.326 & 0.413 & 0.105 & 32.2 & 25.4 \\
\hline MP & $41 / 2-6$ & 0.190 & 0.354 & 0.075 & 39.5 & 21.9 \\
\hline RL & $41 / 2-6$ & 0.301 & 0.336 & 0.096 & 31.0 & 28.6 \\
\hline JG & $6^{1 / 2}-8$ & 0.294 & 0.433 & 0.191 & 65.0 & 44.1 \\
\hline TS & $6^{1} /_{2}^{2}-8$ & 0.139 & 0.198 & 0.121 & 87.1 & 61.1 \\
\hline
\end{tabular}

Table 7. Excess ${ }^{13} \mathrm{C}$ enrichments in carbon 1 of glutamate and carbons 3 and 4 of glucose at times of collection

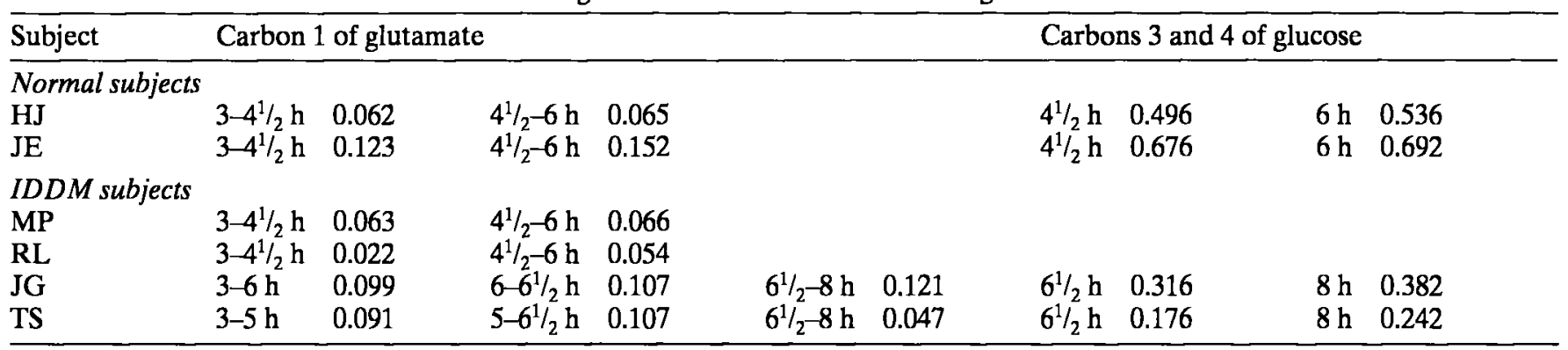

In the 60 -h fasted normal subjects blood glucose was similarly enriched at $4 \frac{1}{2}$ and $6 \mathrm{~h}$ (Table 7). Enrichments in blood glucose in the diabetic subjects $1 \frac{1}{2} \mathrm{~h}$ before the end of infusion were still 20 to $30 \%$ less than at the end of the infusion.

\section{Discussion}

Carbons 1, 2 and 3 of $\alpha$-ketoglutarate, the precursor of glutamate, are from carbons 4,3 and 2 of oxaloacetate [4]. $\left[3-{ }^{14} \mathrm{C}\right]$ Lactate via $\left[3-{ }^{14} \mathrm{C}\right]$ pyruvate forms [3${ }^{14} \mathrm{C}$ ]oxaloacetate. ${ }^{14} \mathrm{C}$ in carbon 2 compared to that in carbon 3 of glutamate (Table 1) is then a function of the extent of equilibration of oxaloacetate with fumarate relative to the other fates of oxaloacetate. ${ }^{14} \mathrm{C}$ from $\left[3-{ }^{14} \mathrm{C}\right]$ lactate is incorporated into carbon 4 of oxaloacetate, and hence carbon 1 of glutamate, by the conversion of $\left[2,3-{ }^{14} \mathrm{C}\right] \alpha$-ketoglutarate to $[1,2,3,4$ ${ }^{14} \mathrm{C}$ ]oxaloacetate via the Krebs cycle and by ${ }^{14} \mathrm{CO}_{2}$ fixation by pyruvate. Since ${ }^{14} \mathrm{C}$ in carbon 1 has been corrected for incorporation due to fixation, that ${ }^{14} \mathrm{C}$ relative to the ${ }^{14} \mathrm{C}$ in carbons 2 and 3 is the measure of cycle flux relative to the conversion of oxaloacetate to PEP. ${ }^{14} \mathrm{C}$ in carbon 4 reflects the decarboxylation of pyruvate to acetyl-CoA relative to its other fates. ${ }^{14} \mathrm{C}$ in carbon 5 is a measure of pyruvate cycling, i.e. pyruvate $\rightarrow$ oxaloacetate $\rightarrow \mathrm{PEP} \rightarrow$ pyruvate.

The rates for the two 60-h fasted subjects (Table 3) agree with our previous finding on giving [3- $\left.{ }^{14} \mathrm{C}\right]$ lactate in an identical manner to three other subjects, although the equilibration of oxaloacetate with fumarate was less [4]. The flux of PEP to pyruvate was about one-half the flux of pyruvate to oxaloacetate (Table 3 ), also in accord with previous estimates $[4,6]$. The contribution of Cori cycling cannot be differentiated from that of pyruvate cycling and the estimate relies on low incorporations. ${ }^{14} \mathrm{C}$ in carbon 4 of glutamate from the $4 \frac{1}{2}-6 \mathrm{~h}$ collections of the subjects fasted $60 \mathrm{~h}$, as before [4], averaged five times the ${ }^{14} \mathrm{C}$ in carbon $5 .{ }^{14} \mathrm{C}$ in carbon 3 of PEP was about 1.2 times that in its carbon 2 as evidenced by distributions in glucose. ${ }^{14} \mathrm{C}$ in carbon 3 of circulating lactate in the previous study was about nine times that in carbon 2 at $6 \mathrm{~h}$. If ${ }^{14} \mathrm{C}$ in the acetylCoA forming carbons 4 and 5 of glutamate had come solely from PEP via pyruvate cycling a ratio of ${ }^{14} \mathrm{C}$ in carbon 4 to 5 of 1.2 would have been expected and 9 if solely from lactate. That it was 5 , while assumptions are many and the percentages small, then suggests that pyruvate and Cori cycling each contributed half.

The metabolic state of the diabetic subjects was more likely to be heterogeneous than for the normal subjects. Furthermore, the rates being relative, do not provide a measure of the absolute rates of gluconeogenesis. In starvation and uncontrolled diabetes, the major hepatic energy source derives from the formation of NADH and $\mathrm{FADH}_{2}$ in fatty acid oxidation to acetyl-CoA, which results in ketosis, similar in de- 
gree in the two groups. Krebs cycle activity is inhibited by the reduced state of those nucleotides.

Corrections for ${ }^{14} \mathrm{CO}_{2}$ incorporation from the [3${ }^{14} \mathrm{C}$ lactate averaged about $30 \%$ (Table 1 ). The relative specific activity and ${ }^{13} \mathrm{C}$ enrichment in urea is assumed to reflect the relative specific activity and enrichments of hepatic mitochondrial $\mathrm{CO}_{2}$. Similar percentage corrections using urea and breath $\mathrm{CO}_{2}$ support that assumption (Table 1 ). The reason the corrections estimated using breath $\mathrm{CO}_{2}$ are about $15 \%$ less than those using urea is unknown, but those corrections would result in only a small change in the estimated rates.

Comparisons are for breath $\mathrm{CO}_{2}$ and urea specific activities and ${ }^{13} \mathrm{C}$ enrichments arising from ${ }^{14} \mathrm{C}$ labelled bicarbonate formed by the intracellular metabolism of $\left[3-{ }^{14} \mathrm{C}\right]$ lactate and ${ }^{13} \mathrm{C}$-labelled bicarbonate infused intravenously. For the comparisons changes in specific activities within tissues should then parallel those of enrichment. This was reasonably achieved (Table 4).

Support for use of the phenylacetylglutamine derivative is found in similar distributions of ${ }^{14} \mathrm{C}$ in the carbons of glucose and glutamate derived from oxaloacetate [4]. Since the glucose carbons arise from hepatic oxaloacetate, presumably the glutamate carbons were also derived from the same oxaloacetate source. That could only occur by the conversion of hepatic $\alpha$-ketoglutarate to glutamine that conjugates with phenylacetate. Further evidence is found in a correction of about $30 \%$ for the contribution of ${ }^{14} \mathrm{CO}_{2}$ fixation to the ${ }^{14} \mathrm{C}$ in carbon 1 of glutamate and carbons 3 and 4 of glucose. Additional support comes from similar distributions of ${ }^{14} \mathrm{C}$ from $[2,3-$ $\left.{ }^{14} \mathrm{C}\right]$ succinate, $\left[2-{ }^{14} \mathrm{C}\right]$ propionate and $\left[3-{ }^{14} \mathrm{C}\right]$ lactate in phenylacetylglutamine from normal subjects fasted $60 \mathrm{~h}$ coupled with evidence for extensive metabolism of $\left[2,3-{ }^{14} \mathrm{C}\right]$ succinate and $\left[3-{ }^{14} \mathrm{C}\right]$ lactate in liver [7]. Still further support comes from estimates similar to ours from the distribution of ${ }^{13} \mathrm{C}$ in glutamate on perfusing liver from fasted rats with $\left[3-{ }^{13} \mathrm{C}\right]$ lactate [8] and on isotopomer analysis of liver glutamate from rats given $\left[\mathrm{U}-{ }^{13} \mathrm{C}\right]$ lactate and $\left[2,3-{ }^{13} \mathrm{C}\right]$ lactate [9].

Correction for $\mathrm{CO}_{2}$ fixation in the normal subjects was again generally about $30 \%$ for both glutamate and glucose (Tables 1 and 2). For subjects KR and $\mathrm{MP}$, corrections were less for glucose than glutamate. However, those were the subjects in whom corrections using breath $\mathrm{CO}_{2}$ specific activities and enrichments were higher than those using urea. While that raised concern about the urea measurements, no error was found.

Ratios of ${ }^{14} \mathrm{C}$ in the carbons of glutamate and glucose derived from carbons 2 and 3 of oxaloacetate are similar for the normal subjects fasted $60 \mathrm{~h}$ (Table 5), but in the diabetic subjects, the average ratio of 1.16 suggests less isotopic equilibration of carbons 3 and 2 of the oxaloacetate used in the formation of the glutamate than glucose. There is evidence for two pools of oxaloacetate in the liver [7-10]. One would then be mitochondrial, with relatively incomplete isotopic equilibration and the source of the glutamate carbons. The other would arise by transport of mitochondrial oxaloacetate into the cytosol and then further isotopic equilibration before conversion to glucose. Alternatively, some labelled $\alpha$-ketoglutarate converted in the diabetic subjects to glutamine was not from the liver, or the difference could reflect a heterogeneity in hepatocytes [11].

The possibility of cytosolic and mitochondrial pools of oxaloacetate is tempered by the suggestion of less isotopic equilibration in the carbons from oxaloacetate in glucose than glutamate when individuals fasted overnight were infused with glucose and given $\left[3-{ }^{14} \mathrm{C}\right]$ lactate and phenylacetate [4]. Lower specific activities in glutamate from glutamine (Table 1) than in glucose (Table 2) are in accord with much of the glutamine used in the conjugation of phenylacetate being unlabelled and coming from muscle $[12,13]$.

${ }^{14} \mathrm{C}$ in carbon 2 to $\mathrm{l}$ of glutamate overlap ${ }^{14} \mathrm{C}$ in carbons 1 and 6 to ${ }^{14} \mathrm{C}$ in carbons 3 and 4 of glucose (Tables 1 and 2), i.e. 5.0 to 9.3 , excluding subject $J G$, compared to 5.0 to 11.6 , but glucose ratios tend to be more, as was previously observed [4]. This again suggests some difference in the source of the carbons of oxaloacetate for glucose and glutamate formation. The difference in range increases, if the incorporation of ${ }^{14} \mathrm{C}$ in carbon 2 of citrate, the source of which is carbon 3 of oxaloacetate, relative to that in carbon 6 of citrate, the source of which is carbon 1 of oxaloacetate, is taken into account. The range is then 4.9 to 8.0 rather than 5.0 to 9.3 .

A major reservation in estimates of rates of gluconeogenesis from the incorporation of label from a labelled substrate into glucose is uncertainty as to the extent of dilution of label at the level of oxaloacetate $[1,3,4]$. That the rate of gluconeogenesis is 2 or more times the rate of Krebs cycle flux in the uncontrolled diabetic patient means that dilution of the labelled substrate is relatively small. We previously estimated that in the 60-h fasted human, in the conversion of $\left[3-{ }^{14} \mathrm{C}\right]$ pyruvate to glucose, the specific activity of PEP would be about five-sixths the specific activity of intracellular pyruvate [4]. Label is assumed for the estimates [4] only to be lost in significant quantity from the cycle in the conversion of oxaloacetate to PEP (Fig. 1). The same pattern in glutamate formed by livers of fasted rats perfused with [3$\left.{ }^{13} \mathrm{C}\right]$ lactate in vitro and by livers of fasted rats infused with $\left[3-{ }^{13} \mathrm{C}\right]$ lactate in vivo supports that assumption [13].

Inability to determine the specific activity or enrichment of intracellular pyruvate has in the past prevented quantitation. The use of breath $\mathrm{CO}_{2}$ eliminates that problem, since its specific activity or enrichment appears to be a good measure of that in in- 
tracellular $\mathrm{CO}_{2}$ [3]. However, when $\left(1-{ }^{13} \mathrm{C}\right)$ leucine was infused into 60 -h fasted humans, enrichment of breath $\mathrm{CO}_{2}$ was about $15 \%$ less than $\mathrm{CO}_{2}$ in arterial and hepatic vein blood (14).

As in our previous study [3], in the normal subjects fasted $60 \mathrm{~h}, 80 \%$ or more of the glucose produced (assuming no cycling) was by gluconeogenesis (Table 6). This is in accord with gluconeogenesis being the only source of circulating glucose after prolonged fasting, except for small amounts from glycogen [15] and glycerol [16]. In the diabetic subjects the contribution of gluconeogenesis varied, but except for subject TS was much less, averaging about $45 \%$. Uptake of gluconeogenic substrates across the splanchnic bed in IDDM subjects, withdrawn from insulin, has accounted for $32-40 \%$ of splanchnic glucose output $[17,18]$.

Glycogen stores remaining during the period of insulin withdrawal may explain the lower contributions of gluconeogenesis to glucose production in the first three diabetic subjects. We expected the higher contribution in subject JG because the distribution of ${ }^{14} \mathrm{C}$ and specific activity in his blood glucose were similar to that in the normal subjects fasted $60 \mathrm{~h}$. The almost symmetrical labelling of glucose carbons, evidence of nearly complete isotopic equilibration between dihydroxyacetone-3-P and glyceraldehyde-3$P$, has been observed when glycogen is depleted [4].

Since enrichment (Table 7) and specific activities (Table 2) in glucose $1 \frac{1}{2} \mathrm{~h}$ before the end of infusion was less than at the end of the infusion, steady state was not achieved. However, as the contribution of glycogen to glucose production decreases, the specific activity of glucose would be expected to increase. A limitation in achieving steady-state in circulating glucose enrichment in the diabetic subjects was probably their large glucose pool. Until steady-state is achieved, gluconeogenesis may be low because a significant portion of glucose in the blood is in the circulation prior to the administration of ${ }^{13} \mathrm{C}$-bicarbonate. In the two 60-h fasted normal subjects, steady-state was approached as evidenced by the similar enrichments in glucose at $4 \frac{1}{2}$ and $6 \mathrm{~h}$. In the three 60 -h fasted subjects in the previous study [4], glucose and glutamate specific activities are in accord with the results for the two subjects in the present study. The achieving of steady-state for the estimate of relative rates is not a determinant as long as the distribution of ${ }^{14} \mathrm{C}$ in glutamate is not changing. The enrichment of ${ }^{13} \mathrm{C}$ in carbon 1 of glutamate would be expected to increase in time with increasing enrichment in breath $\mathrm{CO}_{2}$.

Acknowledgements. This study was supported by National Institutes of Health grants DK 14507 and P50 HD11089, Fogarty International Center Senior Fellowship Award O 1986, and grant 89-0418 from the Bank of Sweden Tercentenary Foundation.
References

1. Landau BR (1993) Estimating gluconeogenic rates in NIDDM. Adv Exp Med Biol 334: 209-220

2. Gay LJ, Schneiter Ph, Schutz Y, Di Vetta V, Jéquier E, Tappy L (1994) A non-invasive assessment of hepatic glycogen kinetics and post-absorptive gluconeogenesis in man. Diabetologia 37: 517-523

3. Ensemo E, Chandramouli V, Schumann WC, Kumaran K, Wahren J, Landau, BR (1992) Use of ${ }^{14} \mathrm{CO}_{2}$ in estimating rates of gluconeogenesis. Am J Physiol 263: E36-E41

4. Magnusson I, Schumann WC, Bartsch GE et al. (1991) Noninvasive tracing of Krebs cycle metabolism in liver. J Biol Chem 266: 6975-6984

5. Kosugi K, Scofield RF, Chandramouli V, Kumaran K, Schumann WC, Landau BR (1986) Pathways of acetone's metabolism in the rat. J Biol Chem 261: 3952-3957

6. Petersen KF, Cline GW, Blair JB, Shulman GI (1994) Substrate cycling between pyruvate and oxaloacetate in awake normal and 3,3'-5-triodo-L-thyronine-treated rats. Am J Physiol 267: E273-E277

7. Landau BR, Schumann WC, Chandramouli V, Magnusson I, Kumaran K, Wahren J (1993) ${ }^{14}$ C-labeled propionate metabolism in vivo and estimates of hepatic gluconeogenesis relative to Krebs cycle flux. Am J Physiol 265: E636E647

8. Di Donato L, Des Rosiers C, Montgomery JA, David F, Garneau M, Brunengraber H (1993) Rates of gluconeogenesis and citric acid cycle in perfused livers, assessed from the mass spectrometric assay of the ${ }^{13} \mathrm{C}$ labelling pattern of glutamate. J Biol Chem 268: 4170-4180

9. Katz J, Wals P, Lee W-N P (1993) Isotopomer studies of gluconeogenesis and the Krebs cycle with ${ }^{13} \mathrm{C}$-labeled lactate. J Biol Chem 268: 25509-25521

10. Baranyai JM, Blum JJ (1989) Quantitative analysis of intermediary metabolism in rat hepatocytes incubated in the presence and absence of ethanol with a substrate mixture including ketoleucine. Biochem J 258: 121-140

11. Jungermann K, Katz N (1989) Functional specialization of different hepatocyte populations. Physiol Rev 69: 708-764

12. Schumann WC, Magnusson I, Chandramouli V, Kumaran K, Wahren J, Landau BR (1991) Metabolism of [2${ }^{14} \mathrm{C}$ acetate and its use in assessing hepatic Krebs cycle activity and gluconeogenesis. J Biol Chem 266: 6985-6990

13. Beylot M, Soloviev MV, David F, Landau BR, Brunengraber $\mathrm{H}$ (1995) Tracing hepatic gluconeogenesis relative to citric acid cycle activity in vitro and in vivo. $\mathrm{J}$ Biol Chem 270: 1509-1514

14. Nair KS, Ebenstein DB, Wahren J (1993) ${ }^{13} \mathrm{CO}_{2}$ enrichment in hepatic vein versus arterial, peripheral venous and breath samples during $\mathrm{L}-\left(1-{ }^{13} \mathrm{C}\right)$ leucine infusion. Clin Res 41: 124A (Abstract)

15. Rothman DL, Magnusson I, Katz LD, Shulman RG, Shulman GI (1991) Quantitation of hepatic glycogenolysis and gluconeogenesis in fasting humans with ${ }^{13} \mathrm{C}$ NMR. Science 254: 573-576

16. Wahren J, Efendic S, Luft R, Hagenfeldt L, Bjorkman O, Felig P (1977) Influence of somatostatin on splanchnic metabolism in postabsorptive and 60-h fasted humans. J Clin Invest 59: 299-307

17. Wahren J, Felig P, Cerasi E, Luft R (1972) Splanchnic and peripheral glucose and amino acid metabolism in diabetes mellitus. J Clin Invest 51: 1870-1878

18. Wahren J, Hagenfeldt L, Felig P (1975) Splanchnic and leg exchange of glucose, amino acids, and free fatty acids during exercise in diabetes mellitus. J Clin Invest 55: 13031314 